\title{
Concentration of Rift Valley Fever and Chikungunya Viruses by Precipitation
}

\author{
FREDERICK KLEIN, BILL G. MAHLANDT, RALPH R. COCKEY, AND RALPH E. LINCOLN \\ Fort Detrick, Frederick, Maryland 21701
}

Received for publication 11 May 1970

\begin{abstract}
Simple and efficient methods for concentrating Rift Valley fever (RVF) virus and chikungunya (CHIK) virus are described. Ammonium sulfate, potassium sulfate, or alcohol was used as a precipitating agent and the precipitate was resuspended to volumes suitable for further processing and purification. The methods permitted concentration of live RVF virus and CHIK virus about 100 -fold with negligible losses of virus. RVF virus retained a high level of infectivity with potassium aluminum sulfate and alcohol, but CHIK virus retained a higher infectivity level with ammonium sulfate than with potassium aluminum sulfate. The data indicate that serum plays an important role in the concentration of both viruses, at least when the sulfate methods are used.
\end{abstract}

Certain viruses have been concentrated by adsorption to salts and molecular gels, e.g., polioviruses on aluminum hydroxide gels $(14,16)$ and on calcium and aluminum phosphate gel (19), fowl plaque influenza, Newcastle, and mumps viruses on calcium phosphate $(3,15)$ or aluminum phosphate $(5,11)$, and poliovirus and enteroviruses by precipitation with cations $(6,7,10)$, by chromatography on cellulose ion-exchange columns $(8,18)$, and by precipitation with methanol with further purification by elution, ultracentrifugation, and enzymatic treatment $(9,17)$.

In contrast to the methods mentioned above, which require complex equipment, this report describes simple procedures for concentrating Rift Valley fever (RVF) and chikungunya (CHIK) viruses. In these procedures, the viruses are precipitated or adsorbed to ammonium sulfate or potassium sulfate, or they are extracted by an alcohol technique.

\section{MATERIALS AND METHODS}

Viral strains. The small-plaque variant (1) of the pantropic van Wyk strain (V. R. Kaschula, D.V.S. Thesis, Univ. of Pretoria, Pretoria, South Africa) of RVF virus was used. Origin and maintenance of this strain were described earlier (20). The African Chik-2 strain of CHIK virus, harvested $42 \mathrm{hr}$ postinfection, was prepared as a $10 \%$ mouse brain suspension in medium 199 containing $\mathbf{4 0 0}$ units of penicillin and $400 \mu \mathrm{g}$ of streptomycin per $\mathrm{ml}$.

Viral assay procedures. Diluent for RVF virus was one part of medium 199 and two parts of Hanks balanced salt solution ( $\mathrm{v} / \mathrm{v}$ ) supplemented with $10 \%$ calf serum; CHIK virus was diluted in heart infusion broth. Fort Detrick Swiss-Webster strain mice weigh- ing 8 to $10 \mathrm{~g}$ and suckling mice less than $30 \mathrm{hr}$ old were used, respectively, for the RVF and CHIK virus assay. Eight mice per dilution were challenged intracerebrally with $0.03 \mathrm{ml}$ of viral material. Deaths were recorded for 6 days postinoculation; only those occurring after $24 \mathrm{hr}$ were used in the calculation of the $50 \%$ mouse intracerebral lethal dose $\left(\right.$ MICLD $\left._{50}\right)$ by the probit method (4).

Tissue strains and cultural procedure. Two variants of Earle's L cells were used to propagate the RVF virus: (i) a selected clone designated clone $1-1$ made from the L-MA line initially obtained from Donald Merchant, University of Michigan, Ann Arbor, and (ii) the L-DR line obtained from William F. Daniels, Fort Detrick, Frederick, Md. Growth medium for L-MA clone 1-1 was medium 199 supplemented with $0.5 \%$ Bacto-peptone. Medium for the L-DR cells was composed of Eagle's minimal essential medium supplemented with $10 \%$ bovine serum, as modified by Daniels et al. (2). These cultures were routinely plated on Mycoplasma Agar Medium (Grand Island Biological Laboratories, Grand Island, N.Y.) and were found to be free from Mycoplasma-like growth. Cell cultures were routinely grown in antibiotic-free medium. Suspension cultures of cells were grown in shake flasks (21).

Prior to infection with RVF virus, tissue cells near the peak of the log phase were diluted to approximately $2 \times 10^{5}$ cells $/ \mathrm{ml}$ in the same type of growth medium used to produce the culture. RVF at a multiplicity of inoculum (MOI) of either 0.01 or 0.001 [ratio of virus MICLD Mo $_{50}$ to a single tissue cell (20)] was seeded directly into the tissue cell culture. Flasks were incubated at $37 \mathrm{C}$ for $72 \mathrm{hr}$ on a reciprocating shaker [3-inch (7.6-cm) stroke, 100 strokes/min].

A variant of Earle's L cell, CCLI 929, was used to propagate CHIK virus in a monolayer system. Cells were grown in medium 199 supplemented with 
$5 \%$ calf serum and containing 100 units of penicillin and $100 \mu \mathrm{g}$ of streptomycin per $\mathrm{ml}$. At the time of virus inoculation, the growth medium was replaced with fresh medium. An MOI of 2.5 was used to inoculate the 24-hr-old monolayer culture in Roux bottles. After $48 \mathrm{hr}$ of incubation at $37 \mathrm{C}$, the fluids were pooled and titrated in suckling mice.

Concentration of virus. Cellular debris was removed from the RVF virus suspension by low-speed centrifugation $(480 \times g$ for $10 \mathrm{~min}$ ) in a Servall RC-2 centrifuge at $4 C$, and the cold supernatant fluid $(4 C)$ was concentrated on the same day. Cell debris was not a problem with CHIK virus grown in monolayer, so the centrifugation step was not necessary prior to concentration.

Three techniques were employed. In the first, stock solution of $100 \%$ saturated ammonium sulfate was prepared, the $p \mathrm{H}$ was adjusted to 7.4 with $1 \mathrm{~N}$ sodium hydroxide, and, to each original starting volume of cold (4 C) supernatant fluid, stock $\left(\mathrm{NH}_{4}\right)_{2} \mathrm{SO}_{4}$ was added intermittently in small amounts with the $p \mathrm{H}$ maintained at 7.4 by use of $\mathrm{NaHCO}_{3}$. After $15 \mathrm{~min}$, the cold $(4 \mathrm{C})$, treated supernatant fluid was centrifuged for $30 \mathrm{~min}$ at $6,000 \times g$ in the SS-34 rotor of a Servall RC-2 centrifuge operating at $4 \mathrm{C}$. The volume of supernatant fluid was measured and titrated. The precipitate was then suspended in an equal volume of medium 199 plus $10 \%$ bovine serum.

The second concentration technique employed alum [potassium aluminum sulfate, $\mathrm{KAl}\left(\mathrm{SO}_{4}\right)_{2}$. $12 \mathrm{H}_{2} \mathrm{O}$ ] to precipitate the virus from the supernatant fluid. A $5 \%$ stock solution of alum was prepared, and the $p \mathrm{H}$ was adjusted to 7.4 with $1 \mathrm{~N}$ sodium hydroxide. To each 100 -ml volume of cold $(4 \mathrm{C})$ supernatant fluid, $2 \mathrm{ml}$ of $5 \%$ stock solution was added (final concentration of alum was $0.1 \%$ ). The alum stock solution was added intermittently while the $p \mathrm{H}$ was kept at 7.4 with sodium bicarbonate. After $15 \mathrm{~min}$, the cold $(4 \mathrm{C})$, treated supernatant fluid was centrifuged in the SS-34 rotor of a Servall RC-2 centrifuge operating at $4 \mathrm{C}$ for $30 \mathrm{~min}$ at $6,000 \times$ $g$. The volume of the supernatant fluid and precipitate was measured, and they were titrated and retained or discarded as described above.

In the third procedure, the supernatant after tissuecell removal was cooled to $-1 \mathrm{C}$ in a dry ice and water mixture, and precooled absolute methanol $(-10 \mathrm{C})$ was added in a ratio of $1: 5$ (alcohol to virus supernatant). The virus-alcohol mixture was held at $-10 \mathrm{C}$ overnight or approximately 16 to 18 $\mathrm{hr}$, after which the mixture was centrifuged for 30 min at $6,000 \times g$ in the SS-34 rotor of a Servall RC-2 centrifuge operating at $-10 \mathrm{C}$. The supernatant was decanted, and the precipitate was suspended in an equal volume of peptone-supplemented medium 199 with $10 \%$ bovine serum added.

Analysis of data. The techniques utilized to concentrate both RVF and CHIK viruses provide certain known values: i.e., the volume and concentration of (i) the original virus suspension, (ii) the supernatant fluid, and (iii) the precipitate. The concentrations were calculated on both per milliliter and total volume bases. Results reported show the degree of concentration achieved and the per cent recovery of infectivity.

\section{RESULTS}

The results with both CHIK and RVF viruses provide some direct evidence that the virions are associated with the serum protein and that they are readily concentrated by precipitation with one or the other of the sulfates or the alcohol employed.

Tables 1 and 2 summarize the results obtained with ammonium sulfate and alum, respectively. Both viruses reacted similarly in that larger infectivity losses occurred in serum-free than in serumsupplemented medium. Greater concentration of RVF virus occurred with alum than with ammonium sulfate, and the converse was true for CHIK virus. In all cases, by either of the two precipitation techniques, the volume was reduced $98 \%$ or more. However, two of five attempts to precipitate CHIK virus produced in serum-free medium resulted in no precipitation by ammonium sulfate (Table 1).

Substantial losses in infectivity occurred in both viruses grown in serum-free medium (Table 1) and concentrated by ammonium sulfate precipitation. Although the volume of the virus suspension was effectively reduced to $2 \%$ of the original volume, only 5.2 and $28.5 \%$ of the initial infectivity were recovered in the precipitates for RVF and CHIK viruses, respectively. Similar results were obtained when RVF virus was propagated in serum-supplemented medium and concentrated by this process. The initial volume was reduced to $1 \%$, but only $12.9 \%$ of the original infectivity was recovered in the precipitate. In contrast, when CHIK virus was propagated in serum-supplemented medium and precipitated by this process, a high degree of concentration was achieved. The initial volume was reduced to $2 \%$, with $73.5 \%$ of initial infectivity recovered; however, 1 to $5 \%$ of the original infectivity was found in the supernatant. This demonstrated an overall loss of infectivity of approximately 21 to $25 \%$. Table 3 shows an example of a single test when $3,000 \mathrm{ml}$ of virus suspension was reduced to $60 \mathrm{ml}$ without loss of infectivity.

The original titer of CHIK virus suspensions had no effect on the efficiency of the process, because starting materials with both high $(9.0$ $\left.\log _{10} \mathrm{MICLD}_{50} / \mathrm{ml}\right)$ and low $\left(7.7 \log _{10} \mathrm{MICLD}_{50} /\right.$ ml) infectivity titers were concentrated as much as 100 -fold without appreciable loss of infectivity. This concentration technique proved to be rapid and very convenient for concentrating CHIK virus to volumes suitable for storage and preparative ultracentrifugation.

When ammonium sulfate proved ineffective in concentrating RVF virus, it was postulated that the properties of the two viruses differed either in the isoelectric points of their protein or in the 
TABLE 1. Concentration of Rift Valley fever (RVF) and chikungunya (CHIK) viruses by ammonium sulfate precipitation

\begin{tabular}{|c|c|c|c|c|c|c|c|c|}
\hline \multirow{3}{*}{ Medium } & \multirow{3}{*}{ Sample } & \multicolumn{4}{|c|}{ Infectivity $\left(\log _{10} \mathrm{MICLD}_{60} / \mathrm{ml}\right)$} & \multirow{3}{*}{$\begin{array}{c}\text { Concn } \\
\text { achieved } \\
\text { (vol, \%) }\end{array}$} & \multirow{2}{*}{\multicolumn{2}{|c|}{$\begin{array}{c}\text { Recovered } \\
\text { infectivity (\% } \\
\text { of total vol) }\end{array}$}} \\
\hline & & \multicolumn{2}{|c|}{$\begin{array}{c}\text { Original } \\
\text { suspension }\end{array}$} & \multicolumn{2}{|c|}{ Precipitate } & & & \\
\hline & & Mean & SD & Mean & $\mathrm{SD}$ & & Mean & $\mathrm{SD}$ \\
\hline \multirow[t]{2}{*}{ Serum-free } & RVF (4 replications) & 6.2 & 1.0 & 6.5 & 0.96 & 99 & 5.2 & 2.38 \\
\hline & CHIK (5 replications) ${ }^{a}$ & 7.9 & 0.45 & 8.8 & 0.64 & 98 & 28.5 & 23.4 \\
\hline \multirow{2}{*}{$\begin{array}{l}\text { Serum-supple- } \\
\text { mented }\end{array}$} & RVF (3 replications) & 7.0 & 1.46 & 7.6 & 0.36 & 99 & 12.9 & 8.15 \\
\hline & CHIK (24 replications) & 8.5 & 0.07 & 9.8 & 0.13 & 98 & 73.5 & 12.5 \\
\hline
\end{tabular}

${ }^{a}$ Precipitate was not recovered in two cases; thus, the data for the original suspension are based on five replicates, but all remaining data are based on three.

TABLE 2. Concentration of Rift Valley fever (RVF) and chikungunya (CHIK) viruses by potassium aluminum sulfate precipitation

\begin{tabular}{|c|c|c|c|c|c|c|c|c|}
\hline \multirow{3}{*}{ Medium } & \multirow{3}{*}{ Sample } & \multicolumn{4}{|c|}{ Infectivity $\left(\log _{10} \mathrm{MICL} \mathrm{D}_{50} / \mathrm{ml}\right)$} & \multirow{3}{*}{$\begin{array}{c}\text { Concn } \\
\text { achieved } \\
\text { (vol, \%) }\end{array}$} & \multirow{2}{*}{\multicolumn{2}{|c|}{$\begin{array}{c}\text { Recovered } \\
\text { infectivity } \\
(\% \text { of total vol })\end{array}$}} \\
\hline & & \multicolumn{2}{|c|}{$\begin{array}{l}\text { Original } \\
\text { suspension }\end{array}$} & \multicolumn{2}{|c|}{ Precipitate } & & & \\
\hline & & Mean & $\mathrm{SD}$ & Mean & $\mathrm{SD}$ & & Mean & SD \\
\hline \multirow[t]{2}{*}{ Serum-free } & RVF (10 replications) & 6.9 & 0.38 & 7.2 & 0.56 & 98 & 23.0 & 14.8 \\
\hline & CHIK (6 replications) & 7.7 & 0.32 & 8.3 & 0.33 & 98 & 12.8 & 2.8 \\
\hline \multirow{2}{*}{$\begin{array}{l}\text { Serum-supple- } \\
\text { mented }\end{array}$} & RVF (17 replications) & 6.4 & 0.19 & 8.1 & 0.19 & 99 & 175.5 & 23.4 \\
\hline & CHIK (12 replications) & 8.1 & 0.16 & 8.7 & 0.19 & 98 & 17.5 & 7.8 \\
\hline
\end{tabular}

TABLE 3. Example of the concentration achieved on large volumes of chikungunya (CHIK) and Rift Valley fever ( $R V F)$ virus suspensions

\begin{tabular}{|c|c|c|c|}
\hline Virus & Vol & $\begin{array}{c}\log _{10} \\
\operatorname{MICLD}_{60} / \\
\mathrm{ml}\end{array}$ & $\begin{array}{l}\log \\
\text { total } \\
\text { MICLD }_{60} a\end{array}$ \\
\hline & $m l$ & & \\
\hline $\mathrm{CHIK}^{b}$ & & & \\
\hline Original suspension. . . . & 3,000 & 9.0 & 12.5 \\
\hline Concentrated suspension & $60^{c}$ & 11.4 & 13.2 \\
\hline $\mathrm{RVF}^{d}$ & & & \\
\hline Original suspension. .... & 600 & 6.5 & 9.3 \\
\hline Concentrated suspension & $13^{c}$ & 8.8 & 9.9 \\
\hline
\end{tabular}

${ }^{a}$ Volume $\times \mathrm{MICLD}_{50} / \mathrm{ml}=$ total $\mathrm{MICLD}_{50}$.

${ }^{b}$ Precipitated by ammonium sulfate.

$c$ Volume represents the original precipitate plus an equal volume of suspending medium.

${ }^{d}$ Precipitated by alum.

structure of the protein of the virus particles. Therefore, different precipitants were tested.

Data on the concentration of these two viruses by alum precipitation are given in Table 2 . Both viruses propagated in serum-free medium showed a substantial decrease in volume, but, again, ex- hibited large losses both in infectivity and in recovery of initial infectivity in the precipitate.

In contrast, RVF virus was concentrated by alum precipitation in serum-supplemented medium (Table 2). The volume of RVF virus culture was reduced to $1 \%$ with better than $100 \%$ recovery of initial infectivity in the precipitate. Table 3 shows an example of a single run in which $600 \mathrm{ml}$ of virus suspension was reduced to $13 \mathrm{ml}$ with no loss of infectivity. Infectivity titrations of the supernatant showed a retention of 25 to $50 \%$ of initial infectivity and suggested that more virus was present than in the initial culture. Note that quantitation of results in this paper is based on infectivity and not on number of virus particles present in the culture material. Polsen and Levitt (13) presented evidence suggesting that RVF virus produces infective particles that cannot be sedimented, that are filamentous, and that contain lipoid material. This explanation or that of incomplete virus (12) may explain these results. Conversely, CHIK virus lost $82.5 \%$ of its initial infectivity after alum precipitation, in contrast to $25 \%$ lost after ammonium sulfate precipitation.

Results for precipitation of RVF virus with alcohol were obtained by using one concentration of alcohol $(20 \%)$, one holding period (18 $\mathrm{hr}$ at 
TABLE 4. Concentration of Rift Valley fever virus by alcohol precipitation ${ }^{a}$

\begin{tabular}{|c|c|c|c|c|}
\hline Virus suspension & Vol & $\begin{array}{c}\log _{10} \\
\text { MICLD } \\
\text { ml }\end{array}$ & $\underset{\log _{\text {total }}}{\text { MICLD }_{50}{ }^{b}}$ & $\begin{array}{c}\text { Per cent } \\
\text { re- } \\
\text { covery }\end{array}$ \\
\hline & $m l$ & & & \\
\hline $\begin{array}{c}\text { I. Original sus- } \\
\text { pension } \\
\text { Concentrated } \\
\text { suspension }\end{array}$ & 100 & 7.9 & 9.9 & \\
\hline Replication 1 & $3.8^{c}$ & 9.2 & 9.8 & 79 \\
\hline Replication 2 & 4.2 & 9.0 & 9.6 & 50 \\
\hline $\begin{array}{l}\text { II. Original sus- } \\
\text { pension.. } \\
\text { Concentrated } \\
\text { suspension }\end{array}$ & 100 & 7.8 & 9.8 & \\
\hline Replication 1 & $2.8^{c}$ & 9.2 & 9.6 & 63 \\
\hline Replication 2 & 3.1 & 9.2 & 9.7 & 79 \\
\hline Replication 3 & 3.5 & 9.0 & 9.6 & 63 \\
\hline
\end{tabular}

a Virus strain was the wild pantropic van Wyk strain (1). For all five cultures, supernatant volume was $100 \mathrm{ml}$. Both the per milliliter and total MICLD $_{50}$ values for each of the five supernatants were $<10^{-1}$.

${ }^{b}$ Volume $\times \operatorname{MICLD}_{50} / \mathrm{ml}=$ total MICLD $\operatorname{Mo}_{50}$

c Volume represents the original precipitate plus an equal volume of suspending medium.

$-10 \mathrm{C})$, and one centrifuge speed $(2,000 \mathrm{rev} / \mathrm{min})$ for the concentration of RVF virus particles. This method resulted in concentration of infective virus about 100 -fold with little loss of infectivity (Table 4). The supernatant was completely clarified and void of infectious virus particles after one centrifugation; thus, the time-consuming task of additional centrifugation was eliminated. Quantitation of the precipitate showed 50 to $80 \%$ recovery of infectivity after concentration by this process.

\section{DISCUSSION}

Advantages of the precipitation techniques employed here are that a large volume of material can be concentrated to a volume (Table 3 ) suitable for storage and preparative ultracentrifugation, and that virus infectivity is not lost during the concentration process under conditions favorable for that particular virus (alum and alcohol precipitation for RVF virus and ammonium sulfate precipitation in serum-containing medium for CHIK virus). We cannot explain why one salt (ammonium sulfate) concentrates CHIK virus and another salt (potassium aluminum sulfate) concentrates RVF virus. It is apparent, however, that serum does play an important role in the concentration of both viruses. These concentration techniques further have the advantage of simplicity and a scale-up potential for any volume of culture. They should be particularly useful for purification of antigen for vaccine production. In addition, the alcohol precipitation method appears to offer potential for concentrating viruses that contain essential lipid material and are sensitive to ether or other fat solvents.

\section{ACKNOWLEDGMENTS}

We acknowledge the fine cooperation provided by Howard M. Hodge, who supplied the chikungunya virus material, and we thank Jack L. Davis, who was successful in concentrating chikungunya virus by methanol extraction, for his helpful suggestions and encouragement during these studies.

\section{LITERATURE CITED}

1. Boyle, J. J. 1967. Some characteristics of plaque variants of Rift Valley fever virus. Amer. J. Vet. Res. 125:1027-1031.

2. Daniels, W. F., D. A. Parker, R. W. Johnson, and L. E. Schneider. 1965. Controlled $\mathrm{pH}$ and oxidation-reduction potential with a new glass tissue culture fermentor. Biotechnol. Bioeng. 7:529-533.

3. Elford, W. J., D. M. Chı, I. M. Dawson, V. A. Dudgeon, F. Fulton, and J. Smiles. 1948. Physical properties of the viruses of Newcastle disease, fowl plague, and mumps. Brit. J. Exp. Pathol. 29:590-595.

4. Finney, D. J. 1952. Statistical methods in biological assay. Hafner Publishing Co., New York.

5. Frimmhagen, L. H., and C. A. Knight. 1959. Column purification of influenza virus. Virology 8:198-208.

6. Grossowicz, N., A. Mercado, and N. Goldblum. 1960. A simple method for concentration of live and formaldehydeinactivated poliomyelitis virus. Proc. Soc. Exp. Biol. Med. 103:872-874.

7. Hampil, B., J. L. Melnick, C. Wallis, R. W. Brown, E. T. Braye, and R. R. Adams, Jr. 1965. Preparation of antiserum to enteroviruses in large animals. J. Immunol. 95: 895-908.

8. Hayer, B. H., E. T. Bolton, D. E. Ritter, and E. Ribi. 1959. Simple method for preparation of purified radioactive poliovirus particles: Electron micrograph. Virology 7:462470.

9. Mayer, M. M., H. J. Rapp, B. Roizman, S. W. Klein, K. M. Cowan, D. Lukens, C. E. Schwardt, F. L. Schaffer, and J. Carney. 1957. The purification of poliomyelitis virus as studied by complement fixation. J. Immunol. 78:435-455.

10. Midulla, M., C. Wallis, and J. L. Melnick. 1965. Enterovirus immunizing antigens in the form of cation-stabilized and concentrated virus preparations. J. Immunol. 95:9-12.

11. Miller, H. D., and R. W. Schelsinger. 1955. Differentiation and purification of influenza viruses by adsorption on aluminum phosphate. J. Immunol. 75:155-160.

12. Mims, C. A. 1956. Rift Valley fever virus in mice. IV. Incomplete virus: Its production and properties. Brit. J. Exp. Pathol. 37:129-143.

13. Polson, A., and J. Levitt. 1963. A slowly sedimenting infectious component of Rift Valley fever virus. J. Hyg. 16:451469.

14. Sabin, A. B. 1931. Experiment on the purification and concentration of the virus of poliomyelitis. J. Exp. Med. 56: 307-317.

15. Salk, J. E. 1941. Partial purification of the virus of epidemic influenza by adsorption on calcium phosphate. Proc. Soc. Exp. Biol. Med. 46:709-712.

16. Schaeffer, M., and W. B. Brebner. 1933. Purification of poliomyelitis virus. Arch. Pathol. 15:221-226. 
17. Schwardt, C. E., and P. L. Schaffer. 1956. Purification of poliomyelitis virus. Arch. Pathol. 15:221-226.

18. Taylor, J., and A. F. Graham. 1958. Purification of poliovirus labelled with radiophosphorus. Virology 6:488-498.

19. Taverne, J., I. H. Marshal, and F. Fulton. 1957. The purification and concentration of viruses and virus soluble antigens on calcium phosphate. J. Gen. Microbiol. 19:431-461.
20. Walker, J. S., R. C. Carter, F. Klein, S. E. Snowden, and R. E Lincoln. 1969. Evaluation of factors related to growth of Rift Valley fever virus in suspended cell cultures. Appl. Microbiol. 17:658-664.

21. Weirether, F. J., J. S. Walker, and R. E. Lincoln. 1968. A precise method for replicating suspension cultures of mammalian cells. Appl. Microbiol. 16:841-844. 